IZA DP No. 4616

Gender Differences in Native Preferences towards Undocumented and Legal Immigration: Evidence from San Diego

Catalina Amuedo-Dorantes

Thitima Puttitanun

December 2009 


\title{
Gender Differences in Native Preferences towards Undocumented and Legal Immigration: Evidence from San Diego
}

\author{
Catalina Amuedo-Dorantes \\ San Diego State University \\ and IZA \\ Thitima Puttitanun \\ San Diego State University
}

Discussion Paper No. 4616

December 2009

\author{
IZA \\ P.O. Box 7240 \\ 53072 Bonn \\ Germany \\ Phone: +49-228-3894-0 \\ Fax: +49-228-3894-180 \\ E-mail: iza@iza.org
}

Any opinions expressed here are those of the author(s) and not those of IZA. Research published in this series may include views on policy, but the institute itself takes no institutional policy positions.

The Institute for the Study of Labor (IZA) in Bonn is a local and virtual international research center and a place of communication between science, politics and business. IZA is an independent nonprofit organization supported by Deutsche Post Foundation. The center is associated with the University of Bonn and offers a stimulating research environment through its international network, workshops and conferences, data service, project support, research visits and doctoral program. IZA engages in (i) original and internationally competitive research in all fields of labor economics, (ii) development of policy concepts, and (iii) dissemination of research results and concepts to the interested public.

IZA Discussion Papers often represent preliminary work and are circulated to encourage discussion. Citation of such a paper should account for its provisional character. A revised version may be available directly from the author. 
IZA Discussion Paper No. 4616

December 2009

\section{ABSTRACT \\ Gender Differences in Native Preferences towards Undocumented and Legal Immigration: Evidence from San Diego}

The literature has noted that native views about legal as opposed to undocumented immigration in the U.S. differ. Furthermore, native views about immigration are known to vary by gender. Yet, most surveys do not inquire native men and women about their views with regards to the two distinct immigrant groups, thus impeding an analysis of differences in preferences towards legal and undocumented immigrants from the same sample of natives. Using a recent San Diego County survey, we examine differences in native male and female opinions with regards to legal and undocumented immigration and their determinants. Native preferences towards immigration appear to significantly differ by gender as well as according to immigrants' legal status. In addition, public finance and welfare concerns are among the key factors driving native male and female preferences towards legal and undocumented immigration. However, native women's attitudes are also impacted by concerns regarding the social integration and economic assimilation of undocumented immigrants possibly related to the alleged prejudice factor.

JEL Classification: J61, F22

Keywords: gender, native preferences, undocumented immigration, legal immigration

Corresponding author:

Catalina Amuedo-Dorantes

Department of Economics

San Diego State University

5500 Campanile Drive

San Diego, CA 92182

USA

E-mail: camuedod@mail.sdsu.edu 


\section{Introduction}

Public views about immigration in the U.S. appear sharply divided -about half of respondents in a variety of U.S. surveys indicate they would prefer that the number of legal immigrants allowed to come to live in the U.S. decreased. ${ }^{1}$ Likewise, the public is also divided in their views towards undocumented immigration. For instance, using data for San Diego County, we find that over 50 percent of natives believe that undocumented migrants should be required to go home, whereas slightly below 50 percent of natives believe that undocumented migrants should be granted some kind of legal status. These are all differences noted in the literature by studies that focus on native opinions regarding either legal or undocumented immigration, ${ }^{2}$ as most surveys do not inquire natives about their preferences towards the two distinct types of immigrants. As such, lacking from the literature is an analysis for the same group of natives of the opinions they may hold with regards to legal as opposed to undocumented immigration, and of the factors driving their views.

Using data for San Diego County we find that, while slightly more than half of natives in our sample oppose a generalized amnesty for undocumented immigrants, less than 30 percent of them want the number of legal immigrants admitted into the U.S. to be reduced. Therefore, it is crucial to distinguish between native opinions towards legal as opposed to undocumented immigration, avoiding any extrapolations of native views towards one group to the other group

\footnotetext{
${ }^{1}$ Some examples include: (a) the 1992, 1994, 1996, and 2000 National Election Studies (NES) surveys, where about half of respondents preferred that the number of immigrants permitted to come to the U.S. to live be lowered (Scheve and Slaughter 2001, Hanson et al. 2007a,b), (b) a 1990 Roper poll, in which about half of respondents believed that the level of U.S. immigration should be lowered, and (c) the 1993 New York Times/CBS News poll used by Espenshade and Hempstead (1994), where two thirds of respondents agreed in that immigration levels should be lowered.

${ }^{2}$ Using U.S. data, Citrin et al. 1997, Scheve and Slaughter 2001, and Hanson et al. 2007a,b, among other ones, discuss how native views with regards to legal immigrants are sharply divided. Differences in native opinions regarding undocumented immigrants are discussed in Espenshade and Calhoun 1993.
} 
given that the factors shaping native opinions on legal and undocumented migrants are likely to differ.

In this paper, we distinguish between individual attitudes towards legal as opposed to undocumented immigration into the United States by using data on: (a) native views towards legal immigration, and on (b) native preferences towards the passage of a generalized amnesty similar to the 1986 Immigration Reform and Control Act (IRCA). In particular, we are interested in finding out whether there are differences in how native men and women feel about legal as opposed to undocumented migrants and, if so, why. In line with the existing literature on native attitudes towards immigration, we examine the role played by a variety of economic and social factors in shaping native distinct preferences over legal and undocumented immigration. In particular, we focus on three broad explanations for differences in native male and female preferences over the two types of immigration: 1) fears of labor market competition; 2) the alleged economic burden imposed by undocumented migrants, and 3) prejudice towards immigrant groups. In sum, we ask ourselves the following questions: Are there differences in native views towards legal as opposed to undocumented immigration? Are these differences found in both native men and native women? And, if so, what explains such differences in native male and female opinions with regards to legal and undocumented immigration?

A number of empirical studies have used survey data to assess the relevance of economic and social factors in explaining individual attitudes towards immigration. Some of the literature focuses on Great Britain, ${ }^{3}$ some on the United States ${ }^{4}$ and, yet others, on a cross-section of

\footnotetext{
${ }^{3}$ See, for instance, Dustmann and Preston (2001, 2007).

${ }^{4}$ Examples of this literature include: Espenshade and Calhoun (1993), Espenshade and Hempstead (1996), Binder $e t$ al. (1997), Citrin et al. (1997), Kessler (2001), Scheve and Slaughter (2001), Richardson (2005) and Hanson et al. (2007a).
} 
countries. ${ }^{5}$ Our study differs from the previous literature with regards to the questions being asked and the data being used. Indeed, owing to survey design, the past literature on native attitudes towards immigration has primarily centered on native preferences for legal immigration. ${ }^{6}$ Only a few studies have focused on native attitudes towards undocumented immigration (Espenshade and Calhoun 1993, Espenshade 1995, Binder et al. 1997) and, to our knowledge, none has compared native preferences towards legal as opposed to undocumented immigration from the same group of male and female respondents. In this study, owing to the information on preferences over legal immigration as well as over an amnesty for undocumented immigrants collected from the same individuals, we are able to contrast and compare respondents' answers to both questions and learn about the factors driving their distinct opinions. Additionally, due to the different views towards immigration held by men and women, ${ }^{7}$ we carry the analysis of natives' preferences towards legal as opposed to undocumented immigration separately by gender.

For the analysis, we rely on an innovative survey carried out in San Diego County in 2005. Despite its restricted geographic focus, this one-time survey allows for an interesting case study regarding native preferences towards undocumented immigration -as captured by their approval of a new generalized amnesty- in the most transited border region of the world.

\footnotetext{
${ }^{5}$ Some examples include: Bauer et al. (2000), Gang et al. (2002), Kessler and Feeman (2005), Mayda (2006), O’Rourke and Sinnott (2006), and Hainmueller and Hiscox (2007).

${ }^{6}$ The vast majority of the U.S. literature focuses on legal immigration as it relies on natives' responses to the question of whether the number of immigrants permitted to come to the U.S. to live should be increased, left the same, or decreased (Citrin et al. 1997, Scheve and Slaughter 2001, Hanson et al. 2007a). A few studies rely on a more general question, such as whether the immigration should be kept at its present level, increased or decreased (Espenshade and Hempstead 1996) or whether the person favors a restriction or suppression of foreign immigration (Richardson 2005). These studies, however, are unable to distinguish between native views towards legal as opposed to undocumented immigration. As such, they implicitly assume that native preferences regarding legal and undocumented immigration are the same.

${ }^{7}$ In both Mayda (2006) and Hainmueller and Hiscox (2007), gender is found to play a significant role in affecting attitudes towards migration. Additionally, Knight et al. (2007) use information from the Chicago Area Survey to examine attitudes towards immigration and find that they differ by gender, especially for the Non-Latino White population.
} 
Indeed, due to its high exposure to undocumented immigration ${ }^{8}$ and the fact that the vast majority of the pre-1982 IRCA applicants resided in California, this is a region where issues surrounding undocumented migration are likely to be most prominent. ${ }^{9}$ Furthermore, the survey was implemented in 2005. As such, it provides us with a fresher look at native views regarding legal and undocumented immigration. The analysis reveals that both male and female native views towards legal and undocumented migrants differ. Additionally, among men, native views with respect to legal and undocumented immigration appear to be primarily driven by native concerns regarding the cost imposed by immigrants, particularly by undocumented immigrants, via their impact on the healthcare system, higher use of social services and lower tax contributions, i.e. the so-called public finance or welfare factor in the previous literature. Native women views regarding legal and undocumented immigration are also shaped by the public finance and welfare factor, as well as by concerns regarding the social integration and economic assimilation of undocumented immigrants more likely to endorse the so-called prejudice factor.

Gaining a better understanding of the determinants of native attitudes towards undocumented as opposed to legal immigration is important for several reasons. First, the number of unauthorized immigrants currently residing in the U.S. is at an all time high of approximately 12 million undocumented migrants as of March 2006 (Passel 2006). To the extent that these immigrants are generally less educated than other immigrants (Fix and Passel 1994, Tienda and Singer 1995), some researchers have noted that they could increase the supply of low-skilled workers and exert a downward pressure on their wages (Borjas, Freeman and Katz

\footnotetext{
${ }^{8}$ According to an article in the NCTimes from October 24, 2006, by Kert Bardella, an estimated of 272,000 undocumented immigrants lived in San Diego, Imperial and Southern Riverside counties in 2006, which translates to nearly 7 percent of the region's 4 million residents (available at NCTimes.com).

${ }^{9}$ In 2007, the San Diego County Board of Supervisors unanimously approved Fifth District Supervisor Bill Horn's recommendations to recover the County of San Diego's costs of services to undocumented immigrants following the release of a study commissioned by the County that showed that county taxpayers pick up the tab for \$101 million a year in County services to people in the country illegally. See: http://www.co.sandiego.ca.us/cnty/bos/sup5/news/n07925.html
} 
1997, Borjas 2003). ${ }^{10}$ Additionally, other studies have shown that unskilled immigrants, as it is often the case with undocumented migrants, could impose greater fiscal burdens on state and local governments (Smith and Edmonston 1997). Identifying the most prominent determinants of differences in native preferences towards legal versus undocumented immigration can help us understand differences in public opinions with regards to specific immigration policies, depending on the legal status of the immigrant group they target.

Secondly, as pointed out by Scheve and Slaugher (2001), understanding native attitudes towards immigration is of interest as such attitudes can influence future immigration policies. In this regard, our hope is that a better understanding of native attitudes towards the various types of immigration may also help guide policy-making in a way that addresses these public concerns and allows for a much needed immigration reform.

Third, as recently noted by Alan Winters, Susan Martin, Luca Barbone and Jaime de Melo at the Second Conference on Migration and Development at the World Bank, ${ }^{11}$ analyzing native attitudes towards immigration is one of the essential tasks we need to be undertaking in order to gain a better understanding of the factors driving the development of not just immigration policy, but also trade patterns and even culture. This is particularly true for a country of immigrants, such as the U.S.

Finally, as pointed out by Mayda (2006), understanding native attitudes towards immigration is also of interest as such attitudes can influence future immigration flows by affecting migrants' incentives to move.

\footnotetext{
${ }^{10}$ Other studies, however, find that undocumented immigrants can serve as complements to other workers (Bean et al. 1988) or that the wage impact of low-skilled immigration was small (Borjas 1999).

${ }^{11}$ See: http://econ.worldbank.org/programs/migration
} 


\section{What Do We Know About Natives' Attitudes towards Immigration?}

The literature on native attitudes towards immigration has quickly grown over the past two decades. Overall, the literature has focused on examining the economic and non-economic factors driving native preferences towards immigration. Specifically, one strand of this literature uses survey data to test the predictions of well-established economic theories, such as extensions to the Heckscher-Ohlin trade model and the factor proportion model. According to these models, low and high-skilled immigration will be opposed by equivalently skilled native groups since immigrants increase the national supply of workers with their skill level and, as a result, lower their wages. Empirical support for this so-called labor market competition hypothesis using education or occupation as a measure of skill and examining its relationship to native preferences over an immigrant group assumed to be similarly skilled is found in several studies, including Scheve and Slaughter (2001) in the U.S. and O'Rourke and Sinnott (2003) and Mayda (2006) for large country cross-sections. ${ }^{12}$

A second economic factor affecting the attitudes towards immigration considered in this literature relates to public finance and welfare concerns. Low-skilled immigrants, often less educated, are expected to earn relatively low wages, to contribute relatively little in taxes, and to consume more out of public services than residents. In this regard, Dustmann and Preston (2004) point out that these implied additional tax burdens fall more heavily on the rich and result in different opinions across skill groups and income classes. In their analysis of the European Social Survey data, they find supportive evidence of native attitudes towards immigration being heavily influenced by public burden concerns. Focusing on the U.S., Hanson et al. (2007a) further hypothesize that natives may expect higher-skilled immigrants to generate positive net

\footnotetext{
${ }^{12}$ In particular, these studies find that low-skilled individuals in developed countries have stronger anti-immigration sentiments since most immigrants to these countries are also low-skilled.
} 
fiscal transfers to native households. As such, they should be more opposed to low-skilled immigrants and less opposed to high-skilled immigrants. However, their findings do not support the hypothesis of high-skilled immigrants being more welcomed due to the perceived public benefit. Instead, their results are more supportive of the labor market competition hypothesis.

Apart from the two economic reasons mentioned above, a variety of non-economic factors have also been found to impact native attitudes towards immigration. For instance, the literature has often focused on the so-called prejudice motive. In this regard, Hainmueller and Hiscox (2007) argue that ethnic and racial tolerance and preference for cultural diversity can explain the strong negative relationship between educational attainment and anti-immigration sentiments found in several articles (see, for example, Citrin et al. (1997) and Chandler and Tsai (2001) for the U.S., and Gang et al. (2002) for Europe). After all, education fosters tolerance by increasing students' knowledge of foreign cultures, encouraging critical thinking, and generating more diverse social networks. In their empirical analysis of 22 European countries, Hainmueller and Hiscox (2007) find that people with higher education levels are more likely to favor immigration regardless of where the immigrants come from and their skill levels. Likewise, Espenshade and Hempstead (1996) for the U.S. and Mayda (2006) using a sample of 23 countries find support for the hypothesis that non-economic factors, ranging from cultural issues to political views, impact natives’ immigration preferences. More recently, using British data, Dustmann and Preston (2007) also find that racial and cultural prejudice is one of the important underlying channels through which overall attitudes are driven, in particular for low-skilled natives.

In any event, the aforementioned studies have focused on native attitudes towards legal or, more generally, overall immigration without distinguishing between legal and undocumented 
immigration. Yet, as noted earlier, such a distinction is important for various reasons. First, it is natural for natives to hold different opinions with regards to legal and undocumented immigration due to a variety of factors, such as views on fairness for those following immigration rules. Secondly, the focus on undocumented immigration is increasingly more important due to the growing stock of undocumented migrants in the country. A few studies have looked into natives' preferences towards undocumented immigration in the U.S. In particular, Espenshade and Calhoun (1993) focus on Southern Californians' attitudes towards undocumented migrants using data collected in a June 1983 survey from a total of 1,031 interviews. They find weak support for a labor market competition hypothesis. Instead, they find that education, cultural affinity, perceived costs and benefits from immigration and political views do a better job in explaining natives' views towards illegal immigration. Additionally, Binder et al. (1997) also compare the factors influencing the views of Mexican Americans and Anglos towards a variety of immigration issues, including illegal immigration, using data from 755 individuals in Hidalgo and Cameron counties along the Texas-Mexico border. They also find that a range of factors, from socio-economic to cultural factors, affect immigration views. Yet, to our knowledge, none of the studies in the literature has examined the factors driving male and female native views regarding legal and undocumented immigration from the same group of respondents or using recent data.

\section{Data and Some Descriptive Evidence}

The data used in this study come from a recent survey sponsored by San Diego State University (SDSU) and carried out by the SDSU Social Science Research Laboratory (SSRL) between July 7, 2005 and January 27, 2006. The first San Diego Area Study included a total of 1,929 randomly selected respondents who, over a 45-minute telephone survey, were interviewed 
over a wide range of topics with a focus on issues pertaining to immigration and immigrants. SSRL employed a variety of quality control measures, including a pilot survey to identify measurement issues and a rigorous interviewer training specific to this project. Details regarding sampling methods and other survey characteristics can be found in the data appendix.

For the purposes of our study, we focus on a sample of up to 1,000 natives for whom we have complete information on the variables used in the analysis. ${ }^{13}$ Our focus is on survey answers to the two following questions:

First question: Currently, U.S. immigration policies allow a certain number of people from different groups to enter the United States each year. Overall, do you think the U.S. should?

(1) increase the number of people allowed to immigrate here legally,

(2) maintain the current number of people allowed to immigrate legally,

(3) decrease the number of people allowed to immigrate here legally.

Second question: As you may know, in 1986 the U.S. Congress passed the Immigration Reform and Control Act, which granted amnesty to nearly two million persons who had lived continuously in this country for 4 or more years without proper documentation. This amnesty law allowed these immigrants to remain here as permanent residents and to apply for U.S. citizenship. At this time, do you think repeating this amnesty program would be?

(1) a good thing,

(2) a bad thing.

In addition to the above options, the survey also allows for “don’t know” (DK) and "refuse to answer” (REF) responses, which we exclude in the construction of our dependent variables. ${ }^{14}$ We use the answers to the first question to create a variable we call Restrict Legal Immigration, which equals 1 for individuals who indicate that "the U.S. should decrease the number of people allowed to immigrate here legally”. Subsequently, we use respondents’ answers to the second question to create a variable we label Oppose Amnesty for Undocumented Immigrants, which equals 1 for individuals who indicate that "repeating the amnesty program would be a bad thing”.

\footnotetext{
${ }^{13}$ Exact sample sizes vary by model specification.

${ }^{14}$ Results do not seem to significantly change when we include the DK and REF responses.
} 
Given the stock of undocumented migrants in the country, this variable provides us with particularly opportune information. Additionally, it helps us gauge native views with regards to undocumented immigration. After all, although opposing a generalized amnesty is not equivalent to favouring a decrease in illegal immigration, both are positively correlated for the purpose of the analysis. In particular, of interest to us is the fact that individuals opposing a generalized amnesty are also likely to oppose an increase in undocumented immigration.

Table 1 displays the mean values for our key variables according to natives' gender. Fifty-six percent of native women and 57 percent of native men are against a new amnesty program, whereas only 31 percent of native women and 25 percent of native men think that legal immigration should be reduced. Furthermore, we find that a significant fraction of natives differentiates between legal and undocumented immigration. Approximately 34 percent of native women and 38 percent of native men oppose an amnesty program for undocumented migrants, but do not want to reduce legal immigration. In contrast, an additional 6 percent of native women and 5 percent of native men do not oppose an amnesty program for undocumented migrants, but wish to reduce legal immigration. As such, simply focusing on native opinions regarding either legal or undocumented immigration and assuming that native opinions regarding legal or undocumented immigration are the same would neglect approximately 40 percent of respondents with distinct views regarding the two types of immigration.

To learn more about native opinions with regards to immigration, we turn our attention to years of education -a factor often used by the literature on native views on immigration in order to test the validity of labor market competition/factor endowment, public finance/welfare and prejudice models as explanations for native preferences regarding immigration. First, we look at whether natives' views regarding undocumented and legal immigration differ according to their 
educational attainment. Figures 1 and 2 plot the percentage of male and female natives, respectively, in favour of reducing legal immigration (i.e. Restrict Legal Immigration) and the percentage opposing a renewed amnesty program for undocumented migrants (i.e. Oppose Amnesty for Undocumented Immigrants) by education attainment level. Native views towards legal and undocumented immigration seem to differ both by gender and, in particular, by educational attainment. Specifically, the gap between the percentage of male and female natives in favour of reducing legal immigration and the percentage opposing a renewed amnesty program for undocumented migrants widens with educational attainment. The gap jumps from approximately 8 (14) percentage points among male (female) natives with a high school diploma, to about 40 (35) percentage points among native men (women) with 18 years of schooling. Consequently, Figures 1 and 2 underscore three facts: (a) native men and women differ in their views with regards to legal and undocumented immigration, (b) the extrapolation of native attitudes towards legal immigrants to undocumented immigrants, and vice versa, can be misleading of native preferences regarding immigration, and (c) education is an important factor in explaining differences in native opinions with regards to legal and undocumented immigration. In particular, to the extent that more educated natives seem to oppose undocumented migration over legal migration more than their less educated counterparts, the descriptive evidence seems to suggest that, perhaps, public finance and welfare concerns are one of the main explanations for the greater native opposition to undocumented as opposed to legal immigration.

The first San Diego Area Study also includes native responses to a series of questions regarding their beliefs about undocumented immigrants paying their share of taxes, using social services, competing with natives for jobs or adversely impacting the healthcare system, among 
other ones. ${ }^{15}$ This information is particularly useful when trying to identify specific native concerns with regards to undocumented immigration. According to Table 2, a significant fraction of natives (above 50 percent) believe that undocumented migrants do not pay their share of taxes (only 24 percent of native men and 18 percent of native women believe they do), overuse social services, do not learn English fast enough, compete with natives for jobs and impact negatively the healthcare system.

Finally, to control for each individual's background, socioeconomic status and political affiliation, we include information on the following respondent characteristics: gender, ethnicity, immigrant background, age, marital status, number of children, work status, income, housing ownership, religious activities and political tendency. We also create two explanatory variables: network and intolerance. The variable network is intended to capture the fact that, by socializing with other ethnic groups, natives may have greater sympathy towards immigrants, who often come from other ethnic groups. Specifically, if respondents have close friends from other ethnic groups, socialize with other ethnic groups, or have visitors from other ethnic groups, network equals 1 . In turn, the variable intolerance is intended to capture a discriminatory behaviour with regards to individuals from other ethnic groups, independently of their immigration status. If respondents are not comfortable having individuals from other ethnic groups as their next-door neighbours, close personal friends, family members through marriage, co-workers, classmates or as residents of San Diego County, then intolerance equals 1.

Table A in the appendix provides some summary statistics for our sample of native men and women. Approximately half of the sample is male and the racial break up is rather similar for native men and women. About 75 percent of native men and women are white. Hispanics constitute about 11 to 12 percent of the sample, Asians account for approximately 2 to 3 percent

\footnotetext{
${ }^{15}$ A list of these survey questions can be found in the appendix.
} 
of the native sample, blacks represent about 6 percent of natives, and the remaining 4 to 5 percent of the sample are from other races. An average of 21 to 22 percent of our sample of native women and men has, at the minimum, one immigrant parent and 28 percent were born in San Diego County. Our sample of natives is, on average, forty-four to 46 years old. Fifty-six percent of native men and 58 percent of native women are married, but women have, on average, more children than men. Native men and women have similar educational attainment (about 14 to 15 years of schooling), but women are more likely than men to be unemployed or out of the labor force. The income bracket with the highest concentration of native women is the one with incomes ranging between $\$ 30,000$ and $\$ 49,999$ per year before taxes. However, among native men, it is the one with incomes ranging between $\$ 70,000$ and $\$ 99,999$ per year before taxes. Twenty-seven of native men and 29 percent of native women attend religious services on a weekly basis and an average of 26 percent of both native men and women declares themselves as politically conservative. The majority of our native sample (about 94 percent of native women and 98 percent of native men) associates with people outside their ethnicity; however, fifteen percent of native men and 18 percent of native women feel uncomfortable interacting with people from different ethnic and racial backgrounds.

\section{Empirical Methodology}

The descriptive analysis in the previous sections suggests that native men and women hold different opinions with regards to legal as opposed to undocumented immigration. Additionally, the views held by native men and women with regards to the two immigrant groups seem to significantly differ with native educational attainment.

In what follows, we go one step further and assess the role played by a variety of factors broadly grouped into so-called economic and non-economic factors in explaining native distinct 
preferences over legal and undocumented immigration. In order to do so, we: 1) evaluate the link between the respondent's skill level -as captured by educational attainment, and 2) control for non-economic factors, such as having immigrant parents, the frequency of religious practice, political ideology, having networks and being intolerant of individuals from other ethnic groups. Despite examining native male and female views with regards to legal and undocumented immigration separately, the analysis allows for the error terms in the two-equation system to be correlated via its estimation as a Seemingly Unrelated Bivariate Probit model:

$$
\begin{gathered}
y_{1}^{*}=x_{1} \beta_{1}+e_{1}, \quad y_{1}=1 \text { if } y_{1}^{*}>0,0 \text { otherwise } \\
y_{2}{ }^{*}=x_{2} \beta_{2}+e_{2}, \quad y_{2}=1 \text { if } y_{2}^{*}>0,0 \text { otherwise } \\
\text { with: } \mathrm{E}\left[e_{1}\right]=\mathrm{E}\left[e_{2}\right]=0, \\
\operatorname{Var}\left[e_{1}\right]=\operatorname{Var}\left[e_{2}\right]=1, \\
\operatorname{Cov}\left[e_{1}, e_{2}\right]=\rho \text { and: } \\
\mathrm{P}\left(Y_{1}=y_{i 1}, Y_{2}=y_{i 2}\right)=\Phi_{2}\left[x_{1}, x_{2}, \rho\right]
\end{gathered}
$$

where $\Phi_{2}\left[x_{1}, x_{2}, \rho\right]$ stands for the bivariate normal Cumulative Distribution Function, $y_{1}$ denotes the Restrict Legal Immigration dummy variable (which equals 1 when the corresponding latent variable $y_{1}{ }^{*}$ capturing native opinions with regards to restricting legal immigration is different from zero), and $y_{2}$ denotes the Oppose Amnesty for Undocumented Immigrants dummy variable (which equals 1 when the related latent variable $y_{2}{ }^{*}$ capturing native opinions with regards to a repeated amnesty for undocumented immigrants is different from zero). The vectors $x_{1}$ and $x_{2}$ include the demographic, economic and non-economic factors discussed earlier, along with a variable measuring skill as captured by years of education. We allow the error terms in the two equations to be correlated since, although it is hard to predict whether they are directly or inversely related, a variety of unknown factors (such as positive/negative life experiences with 
legal and/or undocumented immigrants) may drive natives’ opinions towards both legal and undocumented immigration. $^{16}$

One of the most important economic determinants of native preferences regarding immigration is the potential impact of immigration on native labor market outcomes. Low and high-skilled immigration will be opposed by equivalently skilled native groups since immigrants increase the national supply of workers with their skill level and, as a result, lower their wages. According to this labor market competition hypothesis, to the extent that undocumented migrants have lower levels of skill, on average, than do other immigrants (Fix and Passel 1994, Tienda and Singer 1995), more skilled natives should be less likely to oppose an amnesty for undocumented immigrants and more likely to restrict legal immigration. Therefore, the labor market competition hypothesis would predict that the coefficient for years of education variable would be positive in the Restrict Legal Immigration equation and negative in the Oppose an Amnesty for Undocumented Immigrants equation.

A second economic determinant of native preferences over immigration pointed out in the literature relates to public finance and welfare concerns. Specifically, low-skilled immigrants, as is more often the case among undocumented immigrants, are expected to earn relatively low wages, to contribute relatively little in taxes, and to consume more public services than legal immigrants or natives. As such, undocumented immigrants should be more likely than their legal counterparts to constitute a public burden. To the extent that these implied additional tax burdens fall more heavily on the rich, native educational attainment should be inversely related to their likelihood of restricting legal immigration, but directly related to their probability of opposing an amnesty for undocumented immigrants. Thus, the coefficient for years of

\footnotetext{
${ }^{16}$ Table 3 and Table 4 show that the error terms in the two equations are significantly correlated at the 1 percent level. In particular, the rho coefficients in our models are 0.4207 for men and 0.5548 for women.
} 
education variable should be negative in the Restrict Legal Immigration equation, but positive in the Oppose an Amnesty for Undocumented Immigrants equation.

As noted earlier, it is also possible for native views with regards to legal and undocumented immigration to be driven by prejudice. In this regard, Hainmueller and Hiscox (2007) argue that education fosters tolerance by increasing knowledge of foreign cultures, generating a diverse social network and promoting critical thinking. Therefore, more educated natives should be less likely to oppose both undocumented and legal immigrants and the coefficient for years of education variable should be negative in the Restrict Legal Immigration and in the Oppose an Amnesty for Undocumented Immigrants equations.

Nevertheless, given the limited information offered by native educational attainment alone, we also make use of additional information contained in the survey regarding native beliefs with regards to undocumented immigration to more accurately interpret our findings. In particular, we pay special attention to variables closely linked to the three broad explanations for native preferences over immigration: (a) fears of labor market competition -represented by native concerns about undocumented immigrants competing with natives for jobs; (b) the alleged economic burden imposed by immigrants - as noted by native concerns about undocumented immigrants not paying their share of taxes, overusing social services, or adversely impacting the healthcare system; and (c) prejudice towards immigrants -as suggested by native comments regarding undocumented not learning English fast enough, lowering property values, or being more likely to commit crimes. Native beliefs regarding undocumented immigration are included as additional explanatory variables in equation (2) modeling the likelihood that natives Oppose an Amnesty for Undocumented Immigrants. ${ }^{17}$ Additionally, we include a wide range of non-

\footnotetext{
${ }^{17}$ We follow the literature and assume that native beliefs regarding the impact of undocumented immigrants are exogenous and pre-determined, helping shape native attitudes towards undocumented immigration and an amnesty
} 
economic factors possibly driving native views regarding both types of immigration in vectors $\boldsymbol{x}_{\boldsymbol{1}}$ and $\boldsymbol{x}_{2}$ of equations (1) and (2). Specifically, aside from demographic characteristics, we include information on natives' labor force status, homeownership, religiosity, political ideology as well as information on their contacts with people from various ethnicities (the network variable) and on whether they feel comfortable with people from other racial or ethnic backgrounds (the intolerance variable). Finally, to account for gender differences in native attitudes towards immigration, the analysis is carried out separately for native men and native women. ${ }^{18}$

\section{Findings}

Table 3 and Table 4 report our findings for native men and native women, respectively. ${ }^{19}$ In both instances, the coefficient on years of education is negative in the Restrict Legal Immigration equation, with an additional year of education lowering their likelihood of restricting legal immigration by approximately 5 percentage points. This finding contradicts the prediction from the labor market competition hypothesis, according to which more educated natives should oppose legal immigrants, who are more likely to compete with them for jobs. Additionally, the coefficient on natives' educational attainment in the equation modelling their likelihood of opposing an amnesty for undocumented immigrants is positive for men and negative for women. Hence, the coefficients on natives' educational attainment appear to render support to the public finance/welfare hypothesis in the case of men and to the prejudice

\footnotetext{
instead of the other way around. Additionally, our findings regarding the impact of educational attainment appear robust regardless of whether we exclude or include native beliefs in the regression modeling their attitudes towards an amnesty.

${ }^{18}$ We conduct Chow tests to examine whether it is appropriate to carry out the analysis separately by gender. We are able to reject the null hypothesis (according to which the coefficients are the same for men and women) for both equations at the 1 percent level. The test statistic for the first equation is given by: $\chi^{2}(25)=103.42$ and the test statistic for the second equation is equal to: $\chi^{2}(32)=67.91$.

19 We conduct heteroskedasticity and normality tests. We are unable to reject the null hypothesis of homoskedasticity at the 1 percent significance level. Likewise, the residual plots suggest that we have a normal distribution of the error terms. Results are available from the authors upon request.
} 
hypothesis in the case of women. Nevertheless, because the coefficients on educational attainment are not statistically significant in the equation modelling native attitudes towards a future amnesty, we also look at native beliefs regarding undocumented immigrants to gain a better understanding of the factors shaping native views regarding undocumented immigration.

Among native men, three out of six additional dummies regarding native male beliefs about undocumented immigrants are statistically different from zero at the standard significance levels in Table 3: Undocumented pay their share of taxes (with a significantly negative coefficient), Undocumented use more social services (with a significantly positive coefficient), and Undocumented negatively impact health care system (with a significantly positive coefficient). Native men who believe that undocumented migrants pay their share of taxes have a 50 percentage-point lower likelihood of opposing an amnesty for undocumented immigrants. However, native men who believe that undocumented migrants use more social services or negatively impact the health care system have a 17 percentage-point higher likelihood of opposing an amnesty for undocumented immigrants. Note that all three dummies are related to public finance and welfare concerns. Hence, it appears that, indeed, the economic burden imposed by immigrants is one of the key factors explaining the attitudes towards legal and, in particular, undocumented immigration in the case of native men.

What about native women? Just as native men, native women who believe that undocumented immigrants impact negatively the health care system are 25 percentage-points more likely to oppose an amnesty for undocumented immigrants. Hence, public finance and welfare concerns appear to matter to native women as well. Yet, the figures in Table 4 indicate that native women, unlike men, are also concerned about other factors more likely to provide support to the prejudice hypothesis, namely, that undocumented do not learn English fast enough 
and, although only at the 10 percent significant level, that undocumented bring down property values. The significance of these concerns in shaping native women's views regarding an amnesty for undocumented immigrants reveals that women are also concerned about the social integration and economic assimilation of immigrants. We can only hypothesize as for why this

is the case. Perhaps women are more likely to interact with immigrants employed in the domestic service industry or in child care services than men and, as a result, they may be more concerned about immigrants' quick assimilation to American society.

Finally, the figures in Tables 3 and 4 also reveal a few additional factors correlated to native views regarding undocumented, but not legal, immigration. For instance, native men and native women socializing with other ethnic groups (the network variable) appear to exhibit a greater sympathy towards undocumented immigrants and are, respectively, 26 percentage points and 34 percentage points less likely to oppose an amnesty. Additionally, native women who attend religious services on a weekly basis are 14 percentage-points less likely to oppose an amnesty for undocumented immigrants. Yet, native women who are unemployed or out of the labor force seem to be significantly more likely to oppose an amnesty, perhaps viewing undocumented immigrants as a threat to finding employment.

\section{Summary and Concluding Remarks}

Since public views towards immigration appear divided with regards to undocumented and legal immigration, it is only natural to examine the factors behind such differences in opinions. Yet, owing to data limitations, the prior literature has been unable to differentiate between native opinions towards undocumented as opposed to legal immigration from an identical sample of respondents and, instead, it has often assumed that they are both the same. 
In this study, we address that gap in the literature making use of a recent survey containing detailed information on native opinions towards legal and undocumented immigration from the same sample of respondents. Additionally, due to the distinct views towards immigration often held by men and women, we carry the analysis separately by gender. We find that native male and native female opinions with regards to legal and undocumented immigration significantly differ. In particular, up to 38 (34) percent of our sample of native men (women) opposes an amnesty program for undocumented migrants, but does not want to reduce legal immigration. When we further examine the main reasons for such immigration views, we find that, in addition to various non-economic factors, concerns about the economic burden imposed by undocumented immigrants are key in explaining native opinions. In particular, concerns about undocumented migrants not paying their share of taxes, using more social services, and negatively impacting the healthcare system are at the heart of the public finance and welfare concerns of native men. Native women also seem particularly concerned about the potentially negative impact of undocumented immigrants on the healthcare system. Nevertheless, their views regarding an amnesty for undocumented immigrants are also shaped by their concerns about the social integration and economic assimilation of undocumented immigrants as noted by their beliefs that undocumented do not learn English fast enough and that undocumented bring down property values -both arguments more likely to endorse the prejudice hypothesis.

Overall, although our findings should be interpreted with caution due to the small size of our sample, they help reconcile differences in public opinions and in some of the existing literature regarding legal and undocumented immigration. More importantly, they help us understand differences in public opinions with regards to specific immigration policies, depending on the legal status of the immigrant group they target. Our hope is that they may also 
help guide policy-making in a way that addresses these public concerns and allows for a much needed immigration reform. Should we consider an immigration policy that favors the entry of highly-educated immigrants less likely to impose an economic burden on natives? Should we require immigrants to be English proficient? These are all important questions to consider by any immigration reform, along with the existing evidence on the complementarities between unskilled and skilled labor when it comes to employment and income (Peri and Sparber 2009). Similarly, our findings -in particular the concern held by both native men and women regarding the negative impact of undocumented immigrants on the health care system- bring attention to the important and nationally ongoing debate on health care. In conclusions, learning about native views regarding both legal and undocumented immigration is essential in order to gain a better understanding of the direction of future immigration, health care, and even trade policies. 


\section{References}

Bauer, Thomas K., Magnus Lofstrom, and Klaus F. Zimmermann. 2000. “Immigration Policy, Assimilation of Immigrants and Natives’ Sentiments towards Immigrants: Evidence from 12 OECD-Countries”, IZA DP No. 187.

Bean, Frank D., Lindsay B. Lowell and Lowell J. Taylor. 1988. "Undocumented Mexican Immigrants and the Earnings of Other Workers in the United States” Demography, 25: 35-52.

Binder, Norman E., J. L. Polinard, and Robert D. Wrinkle. 1997. "Mexican American and Anglo Attitudes towards Immigration Reform: A View from the Border” Social Science Quarterly, 78(2): 324-337.

Borjas, George J. 1999. “The Economic Analysis of Immigration,” in Orley C. Ashenfelter and David Card, eds., Handbook of Labor Economics, Amsterdam: North Holland, pp. 1697-1760.

Borjas, George J. 2003. "The Labor Demand Curve is Downward Sloping: Reexamining the Impact of Immigration on the Labor Market" The Quarterly Journal of Economics, 118(4): 1335-1374.

Borjas, George J., Robert B. Freeman, and Lawrence F. Katz. 1997. "How Much Do Immigration and Trade Affect Labor Market Outcomes?” Brookings Papers on Economic Activity, 1: 1-90.

Chandler, Charles R. and Yung-Mei Tsai (2001): "Social Factors Influencing Immigration Attitudes: An Analysis of Data from the General Social Survey” The Social Science Journal, 38 (2): 177-188.

Citrin Jack, Donald P. Green, Christopher Muste, and Cara Wong. 1997. "Public Opinion Towards Immigration Reform: The Role of Economic Motivations” The Journal of Politics, 59(3): 858-881.

Dustmann, Christian and Ian Preston. 2001. “Attitudes to Ethnic Minorities, Ethnic Context and Location Decisions” The Economic Journal, 111(April): 353-373.

Dustmann, Christian and Ian Preston (2004): “Is Immigration Good or Bad for the Economy? Analysis of Attitudinal Responses” CReAM Discussion Paper No. 06/04.

Dustmann, Christian and Ian Preston. 2007. "Racial and Economic Factors in Attitudes to Immigration” The B.E. Journal of Economic Analysis \& Policy (Advances), 7(1), Article 62.

Espenshade, Thomas J. 1995. "Unauthorized Immigration to the United States” Annual Review of Sociology, 21: 195-216.

Espenshade, Thomas J. and C. A. Calhoun. 1993. "An Analysis of Public Opinions towards Undocumented Immigration” Population Research and Policy Review, 12: 189-224. 
Espenshade, Thomas J. and Katherine Hempstead. 1996. "Contemporary American Attitudes Towards U.S. Immigration” International Migration Review, 30(2): 535-570.

Fix, Michael and Jeffrey S. Passel. 1994. Immigration and Immigrants: Setting the Record Straight. Washington DC: Urban Institute.

Hainmueller, Jens and Michael J. Hiscox. 2007. "Educated Preferences: Explaining Attitudes Towards Immigration in Europe”, International Organization, 61(2): TBA.

Hanson, Gordon H., Kenneth Scheve, and Matthew J. Slaughter (2007a): "Individual Preferences over High-Skilled Immigration in the United States,” Mimeo, UCSD, Yale University, and Dartmouth College.

Hanson, Gordon H., Kenneth Scheve, and Matthew J. Slaughter (2007b): "Public Finance and Individual Preferences over Globalization Strategies”, Economics \& Politics, Vol. 19, Iss.1, pp. 1-33.

Holbrook, Allyson L., Jon A. Krosnick, and Alison Pfent. 2007. “The Causes and Consequences of Response Rates in Surveys by the News Media and Government Contractor Survey Research Firms.” In Advances in Telephone Survey Methodology, ed. James M. Lepkowski, N. Clyde Tucker, J. Michael Brick, Edith De. De Leeuw, Lilli Japec, Paul J. Lavrakas, Michael W. Link, and Roberta L. Sangster. New York: Wiley.

Gang, Ira N., Francisco L. Rivera-Batiz, and Myeong-Su Yun. 2002. “Economic Strain, Ethnic Concentration and Attitudes towards Foreigners in the European Union” IZA DP No. 578.

Kessler, Alan. 2001. "Immigration, Economic Insecurity, and the 'Ambivalent' American Public” The Center for Comparative Immigration Studies, Working paper no. 41.

Kessler, Alan and Gary Freeman. 2005. "Public Opinion in the EU on Immigration from Outside the Community” Journal of Common Market Studies, 43(4): 825-850.

Knight, Roger, Timothy Ready, and Gia Elise Barboza. 2007. “Attitudes towards Immigration: Findings from the Chicago Area Survey” Latino Research @ND, 4(5): 1-7.

Mayda, Anna Maria. 2006. "Who is Against Immigration? A Cross-Country Investigation of Individual Attitudes Towards Immigrants” The Review of Economics and Statistics, 88(3): 510530.

O’Rourke, Kevin H. and Richard Sinnott. 2005. “The Determinants of Individual Attitudes Towards Immigration” European Journal of Political Economy, 22: 838-861.

Passel, Jeffrey S. 2006. Estimates of the Size and Characteristics of the Undocumented Population. March Report from the Pew Hispanic Center: Washington, D.C. 
Peri, Giovanni and Chad Sparber. 2009. “Task Specialization, Immigration and Wages”, American Economic Journal: Applied Economics, Vol 1:3.

Richardson, Gary. 2005. "The Origins of Anti-Immigrant Sentiments: Evidence from the Heartland in the Age of Mass Migration” Topics in Economic Analysis \& Policy, 5(1), Article 11.

Scheve, Kenneth F., and Mathew J. Slaughter. 2001. "Labor Market Competition and Individual Preferences over Immigration Policy" The Review of Economics and Statistics, 83(1): 133-145.

Smith, James P. and Barry Edmonston, eds. 1997. The New Americans. Washington DC: National Academy Press.

Tienda, Marta and Audrey Singer. 1995. "Wage Mobility of Undocumented Workers in the United States” International Migration Review, 29: 112-38. 
Table 1: Weighted Percent of Natives with Specific Views on Undocumented vs. Legal Immigration

\begin{tabular}{lcc}
\hline & \multicolumn{2}{c}{ Percent } \\
\cline { 2 - 3 } Native Views & Male & \multirow{2}{*}{ Female } \\
\hline Opposes Amnesty for Undocumented Immigrants & 0.57 & 0.56 \\
Restricts Legal Immigration & 0.25 & 0.31 \\
Restricts Legal Immigration and Opposes an Amnesty & 0.15 & 0.17 \\
Does Not Restrict Legal Immigration and Does not Oppose an Amnesty & 0.28 & 0.25 \\
Opposes an Amnesty but Does Not Restrict Legal Immigration & 0.38 & 0.34 \\
Restricts Legal Immigration but Does Not Oppose an Amnesty & 0.05 & 0.06 \\
\hline \hline
\end{tabular}


Figure 1

Male Native Views Regarding Legal and Undocumented Immigration by Educational Attainment

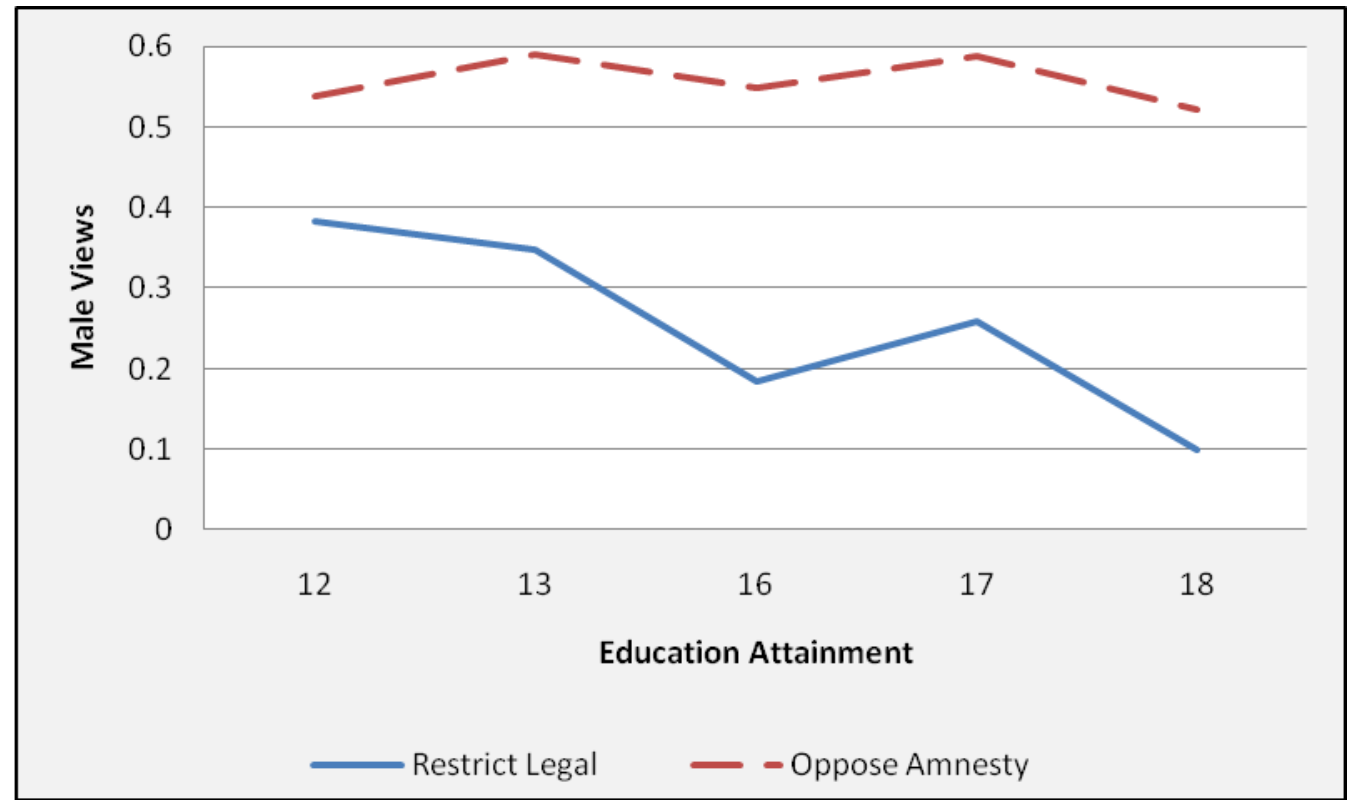

Figure 2

Female Native Views Regarding Legal and Undocumented Immigration by Educational Attainment

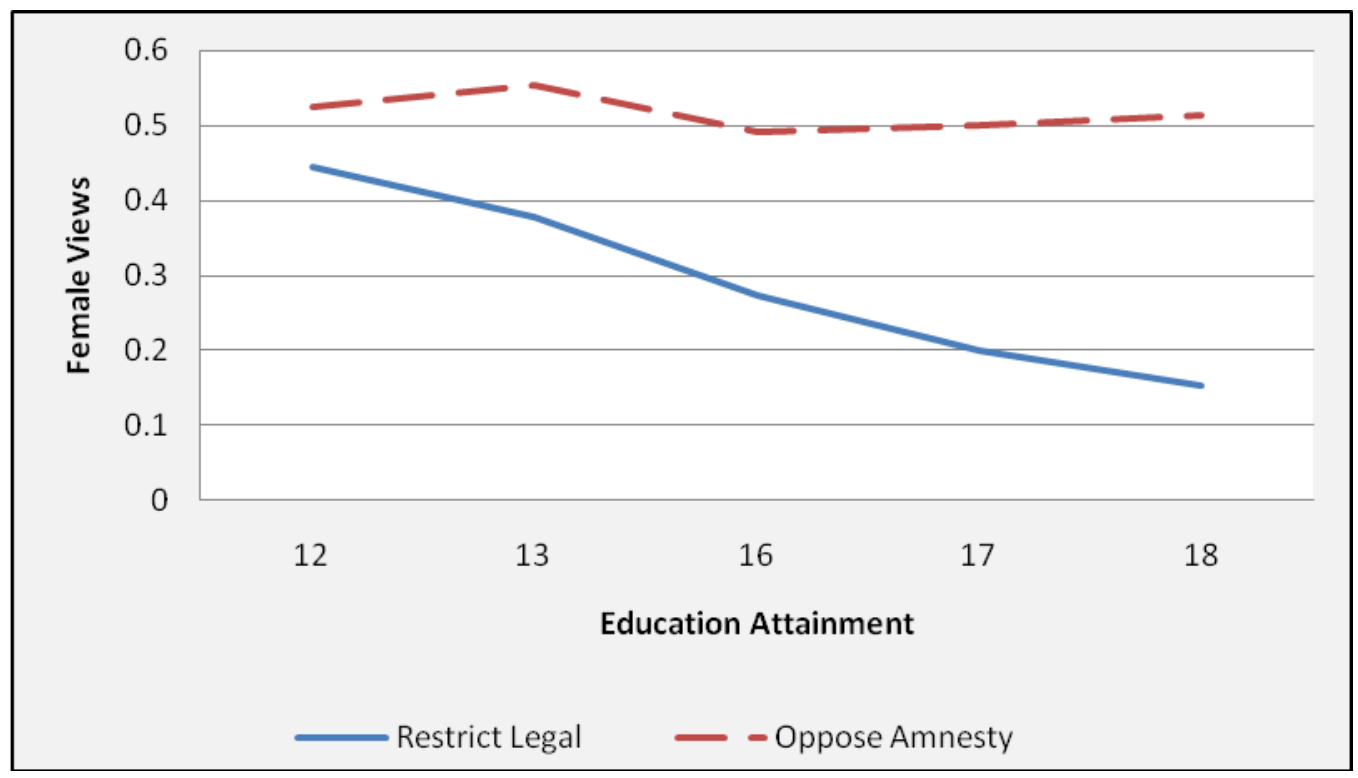


Table 2: Weighted Percent of Natives with Specific Beliefs Regarding Undocumented Immigration

\begin{tabular}{lcc}
\hline \hline & \multicolumn{2}{c}{ Percent } \\
\cline { 2 - 3 } Native Beliefs & Male & Female \\
\hline Undocumented pay their share of taxes & 0.24 & 0.18 \\
Undocumented use more social services & 0.54 & 0.55 \\
Undocumented do not learn English fast enough & 0.70 & 0.69 \\
Undocumented bring down property values & 0.46 & 0.36 \\
Undocumented compete with natives for jobs & 0.61 & 0.53 \\
Undocumented impact negatively the health care system & 0.78 & 0.78 \\
Undocumented are more likely to commit crimes & 0.26 & 0.26 \\
\hline \hline
\end{tabular}


Table 3: Male Natives Views on Legal and Undocumented Immigration

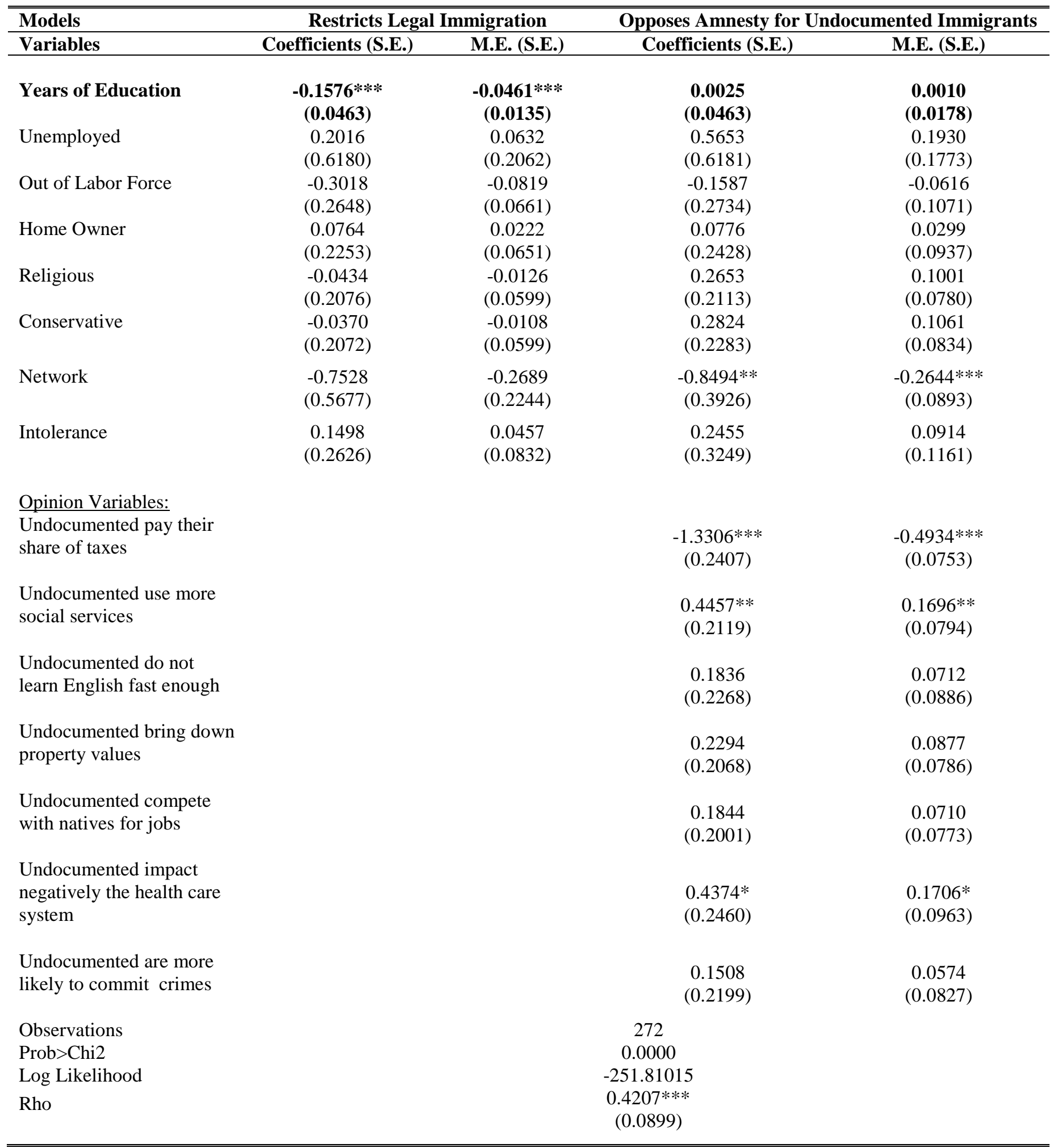

Notes: All regressions include a constant term as well as the following variables shown in Table A: race, second generation, San Diegan, age, marital status, number of children, and 8 income level dummies. Robust standard errors are in parentheses. $* * *, * *, *$ denote $1 \%, 5 \%$, and $10 \%$ levels of significance, respectively. 
Table 4: Female Natives Views on Legal and Undocumented Immigration

\begin{tabular}{|c|c|c|c|c|}
\hline Models & \multicolumn{2}{|c|}{ Restricts Legal Immigration } & \multicolumn{2}{|c|}{ Opposes Amnesty for Undocumented Immigrants } \\
\hline Variables & Coefficients (S.E.) & M.E. (S.E.) & Coefficients (S.E.) & M.E. (S.E.) \\
\hline Years of Education & $\begin{array}{c}-0.1571 * * * \\
(0.0490)\end{array}$ & $\begin{array}{c}-0.0506 * * * \\
(0.0156)\end{array}$ & $\begin{array}{c}-0.0682 \\
(0.0577)\end{array}$ & $\begin{array}{l}-0.0270 \\
(0.0229)\end{array}$ \\
\hline Unemployed & $\begin{array}{c}0.1889 \\
(0.4047)\end{array}$ & $\begin{array}{c}0.0641 \\
(0.1436)\end{array}$ & $\begin{array}{l}1.9221 * * * \\
(0.5426)\end{array}$ & $\begin{array}{c}0.4581 * * * \\
(0.0476)\end{array}$ \\
\hline Out of Labor Force & $\begin{array}{l}-0.0739 \\
(0.2202)\end{array}$ & $\begin{array}{l}-0.0236 \\
(0.0696)\end{array}$ & $\begin{array}{c}0.9375^{* * *} \\
(0.2382)\end{array}$ & $\begin{array}{c}0.3454 * * * \\
(0.0774)\end{array}$ \\
\hline Home Owner & $\begin{array}{l}-0.0599 \\
(0.2112)\end{array}$ & $\begin{array}{l}-0.0193 \\
(0.0684)\end{array}$ & $\begin{array}{c}0.3191 \\
(0.2350)\end{array}$ & $\begin{array}{c}0.1261 \\
(0.0923)\end{array}$ \\
\hline Religious & $\begin{array}{l}-0.2779 \\
(0.2000)\end{array}$ & $\begin{array}{l}-0.0866 \\
(0.0602)\end{array}$ & $\begin{array}{l}-0.3578^{*} \\
(0.2128)\end{array}$ & $\begin{array}{l}-0.1417 * \\
(0.0837)\end{array}$ \\
\hline Conservative & $\begin{array}{c}0.1457 \\
(0.2030)\end{array}$ & $\begin{array}{c}0.0479 \\
(0.0679)\end{array}$ & $\begin{array}{c}0.2737 \\
(0.2284)\end{array}$ & $\begin{array}{c}0.1071 \\
(0.0878)\end{array}$ \\
\hline Network & $\begin{array}{l}-0.2775 \\
(0.4237)\end{array}$ & $\begin{array}{l}-0.0960 \\
(0.1557)\end{array}$ & $\begin{array}{c}-1.0230 * * * \\
(0.3736)\end{array}$ & $\begin{array}{c}-0.3350 * * * \\
(0.0878)\end{array}$ \\
\hline Intolerance & $\begin{array}{c}0.2491 \\
(0.2249)\end{array}$ & $\begin{array}{c}0.0840 \\
(0.0785)\end{array}$ & $\begin{array}{l}-0.1460 \\
(0.2380)\end{array}$ & $\begin{array}{l}-0.0580 \\
(0.0947)\end{array}$ \\
\hline $\begin{array}{l}\text { Opinion Variables: } \\
\text { Undocumented pay their } \\
\text { share of taxes }\end{array}$ & & & $\begin{array}{l}-0.2931 \\
(0.2388)\end{array}$ & $\begin{array}{l}-0.1164 \\
(0.0945)\end{array}$ \\
\hline $\begin{array}{l}\text { Undocumented use more } \\
\text { social services }\end{array}$ & & & $\begin{array}{c}0.1318 \\
(0.2342)\end{array}$ & $\begin{array}{c}0.0522 \\
(0.0927)\end{array}$ \\
\hline $\begin{array}{l}\text { Undocumented do not } \\
\text { learn English fast enough }\end{array}$ & & & $\begin{array}{c}0.5149 * * \\
(0.2317)\end{array}$ & $\begin{array}{c}0.2029 * * \\
(0.0897)\end{array}$ \\
\hline $\begin{array}{l}\text { Undocumented bring } \\
\text { down property values }\end{array}$ & & & $\begin{array}{l}0.3770 * \\
(0.2102)\end{array}$ & $\begin{array}{l}0.1478 * \\
(0.0811)\end{array}$ \\
\hline $\begin{array}{l}\text { Undocumented compete } \\
\text { with natives for jobs }\end{array}$ & & & $\begin{array}{l}-0.3233 \\
(0.2093)\end{array}$ & $\begin{array}{l}-0.1271 \\
(0.0813)\end{array}$ \\
\hline $\begin{array}{l}\text { Undocumented impact } \\
\text { negatively the health care } \\
\text { system }\end{array}$ & & & $\begin{array}{c}0.6390 * * * \\
(0.2366)\end{array}$ & $\begin{array}{c}0.2506 * * * \\
(0.0895)\end{array}$ \\
\hline $\begin{array}{l}\text { Undocumented are more } \\
\text { likely to commit crimes }\end{array}$ & & & $\begin{array}{l}-0.0815 \\
(0.2432)\end{array}$ & $\begin{array}{l}-0.0323 \\
(0.0966)\end{array}$ \\
\hline $\begin{array}{l}\text { Observations } \\
\text { Prob>Chi2 } \\
\text { Log Likelihood }\end{array}$ & & & $\begin{array}{c}257 \\
0.0000 \\
-252.498\end{array}$ & \\
\hline Rho & & & $\begin{array}{c}0.5548 * * * \\
(0.0746)\end{array}$ & \\
\hline
\end{tabular}

Notes: All regressions include a constant term as well as the following variables shown in Table A: race, second generation, San Diegan, age, marital status, number of children, and 8 income level dummies. Robust standard errors are in parentheses. $* * *, * *, *$ denote $1 \%, 5 \%$, and $10 \%$ levels of significance, respectively. 


\section{Data Appendix}

The main objective of the first San Diego Area Study was to learn more about issues pertaining to immigration, immigrants and overall inter-ethnic group relations. Consequently, a probabilistic disproportionate stratified sampling design was used to allow for such a study. Sampling was to ten ethnic by immigrant strata: 1-2) U.S. born and Immigrant Whites, 3-4) U.S. born and Immigrant African Americans, 5-6) U.S. born and Immigrant Hispanic/Latinos, 7-8) U.S. born and Immigrant Asians/Pacific Islanders, and 9-10) U.S. born and Immigrants from all other ethnic groups. Sample weights were developed specifically to reflect the sampling design and to conform our sample to the Census ethnic by nativity distribution. The resulting weighted sample size distribution by stratum exactly mirrors the Census distribution. For instance, 54.7 percent of the weighted sample are white natives -the same as in the Census data.

The secondary sampling frame was a random sample of 67,000 phone numbers for San Diego County residents obtained from Scientific Telephone Samples of Irvine, CA. Participation in the survey was voluntary. A minimum of 7 attempts were made on each telephone number. The median interview length was 43 minutes. Eighty-seven percent of the interviews were conducted in English, ten percent in Spanish, two percent in Mandarin and less than 2 percent in Vietnamese. The response rate was 21 percent, the cooperation rate was $58 \%$ and the refusal rate 17 percent. Holbrook, Krosnick, and Pfent (2007) review the literature on response rates to over 100 random-digit-dialing phone interviews conducted over a 10-year period by leading survey organizations, including the U.S. government. They conclude that there is mixed evidence with regards to the relationship between response rates and sample representativeness. According to their analysis, response rates to telephone surveys range between 4 percent and 70 percent, averaging 30 percent and with declining response rates over time. At any rate, the survey was pilot tested in order to assess readability, skip patterns and other similar problems. No such problems were detected. 


\section{Additional Survey Questions about Native Beliefs Regarding Undocumented Immigrants Used in the Study}

Next, I'm going to read a series of general statements that some people believe, while others do not. For each one, please tell me whether you think it is true or false... . Please keep in mind that there are no right or wrong answers, so please just answer according to your opinion.

1. Undocumented immigrants in San Diego County pay their share of taxes

2. Undocumented immigrants in San Diego County use more social services and public assistance programs than other San Diegans

3. Undocumented immigrants in San Diego County are not learning English fast enough

4. Undocumented immigrants moving into a San Diego neighbourhood bring down property values

5. Undocumented immigrants in San Diego County are competing with other San Diegans for jobs

6. Taking care of the health needs of undocumented immigrants in San Diego County negatively impacts the health care system

7. Undocumented immigrants in San Diego County are more likely than other San Diegans to commit property and violent crimes 
Table A: Weighted Means and Standard Deviations by Gender

\begin{tabular}{|c|c|c|c|c|}
\hline \multirow{2}{*}{ Variables } & \multicolumn{2}{|c|}{ Male } & \multicolumn{2}{|c|}{ Female } \\
\hline & Mean & S.D. & Mean & S.D. \\
\hline White & 0.75 & 0.43 & 0.76 & 0.43 \\
\hline Black & 0.06 & 0.24 & 0.06 & 0.24 \\
\hline Hispanic & 0.12 & 0.32 & 0.11 & 0.32 \\
\hline Asian & 0.03 & 0.16 & 0.02 & 0.15 \\
\hline Other race & 0.04 & 0.21 & 0.05 & 0.21 \\
\hline Second generation (at least one parent is an immigrant) & 0.22 & 0.41 & 0.21 & 0.41 \\
\hline San Diegan & 0.28 & 0.45 & 0.28 & 0.45 \\
\hline Age & 43.56 & 17.04 & 46.07 & 18.34 \\
\hline Married & 0.56 & 0.50 & 0.58 & 0.49 \\
\hline Children & 1.22 & 1.43 & 1.61 & 1.50 \\
\hline Years of education & 14.77 & 2.20 & 14.34 & 2.19 \\
\hline Unemployed & 0.02 & 0.13 & 0.04 & 0.19 \\
\hline Out of labor force & 0.21 & 0.41 & 0.40 & 0.49 \\
\hline \multicolumn{5}{|l|}{ Annual income last year before taxes: } \\
\hline Under $\$ 6,000$ & 0.05 & 0.22 & 0.02 & 0.15 \\
\hline$\$ 6,000$ to $\$ 11,999$ & 0.05 & 0.22 & 0.06 & 0.23 \\
\hline$\$ 12,000$ to $\$ 19,999$ & 0.04 & 0.21 & 0.10 & 0.31 \\
\hline$\$ 20,000$ to $\$ 29,999$ & 0.11 & 0.32 & 0.17 & 0.37 \\
\hline$\$ 30,000$ to $\$ 49,999$ & 0.19 & 0.39 & 0.20 & 0.40 \\
\hline$\$ 50,000$ to $\$ 69,999$ & 0.15 & 0.36 & 0.18 & 0.39 \\
\hline$\$ 70,000$ to $\$ 99,999$ & 0.20 & 0.40 & 0.14 & 0.35 \\
\hline$\$ 100,000$ to $\$ 199,999$ & 0.17 & 0.37 & 0.09 & 0.28 \\
\hline$\$ 200,000$ and more & 0.03 & 0.16 & 0.03 & 0.18 \\
\hline Home owner & 0.57 & 0.50 & 0.57 & 0.50 \\
\hline Attends religious services at least weekly & 0.27 & 0.44 & 0.29 & 0.45 \\
\hline Politically conservative & 0.26 & 0.44 & 0.26 & 0.44 \\
\hline Network & 0.98 & 0.15 & 0.94 & 0.24 \\
\hline Intolerance & 0.15 & 0.36 & 0.18 & 0.38 \\
\hline
\end{tabular}

